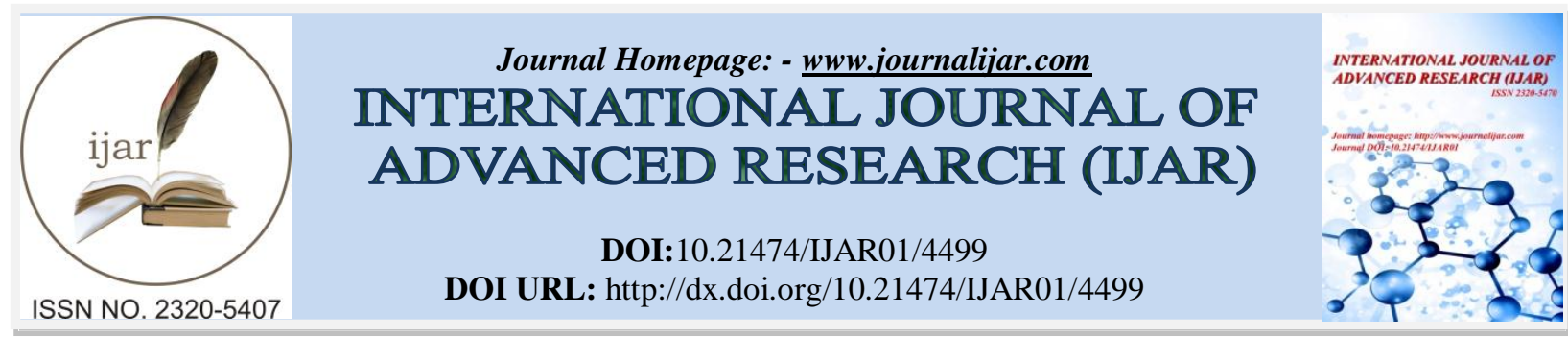

RESEARCH ARTICLE

\title{
ANTIDIABETIC ACTIVITY OF THE AQUEOUS EXTRACTS OF SARCOCEPHALUS POBEGUINII (BARKS) AND NAUCLEA DIDERICHII (LEAVES AND BARKS) IN NORMAL AND STREPTOZOTOCIN INDUCED-HYPERGLYCEMIC RATS.
}

\author{
Mbot Elvis Jolinom ${ }^{1},{ }^{*}$ Agnaniet Huguette ${ }^{1}$, Ngueguim Tsofack Florence ${ }^{2}$, Padzys Guy Stephane ${ }^{3}$ and \\ ** DimoTheophile ${ }^{2}$.
}

1. Laboratory of natural substances and organometallic synthesis, University of Science and Technique of Masuku, Faculty of Science BP. 943, Franceville, Gabon.

2. Department of Animal Biology and Physiology, Faculty of Science, University of Yaounde I, P.o. Box 812, Cameroon.

3. Department of Biology, University of Science and Technique of Masuku, Faculty of Science BP. 943, Franceville, Gabon.

\section{Manuscript Info}

\section{Manuscript History}

Received: 16 April 2017

Final Accepted: 18 May 2017

Published: June 2017

\section{Key words:-}

Nauclea diderrichii, Sarcocephalus pobeguinii, diabetes, streptozotocin, antidiabetic activity

\section{Abstract}

Nauclea diderrichii (barks and leaves) and Sarcocephalus pobeguinii (barks) used in Gabonese traditional medicine for the management of diabetes have been shown to be potent inhibitor of $\alpha$-glucosidase. The present study was aimed to evaluate the antidiabetic activity of the aqueous extract of these plants in normal and streptozotocin induceddiabetic rats. Effect of various doses $(50-400 \mathrm{mg} / \mathrm{kg}$ ) of extract was studied on their hypoglycemic activity. Two effective doses were selected to investigate their antidiabetic effect on streptozotocin induced-diabetic rats. Animals received substances at a unique daily dose for two weeks. Blood glucose levels were determined weekly. Several others parameters were evaluated: lipid profile, serum transaminases, total proteins, creatinin, total and direct bilirubin and uric acid. Some oxidative parameters were also measured. In normal rats, all extract reduced blood glucose levels with a marked effect at the dose of $200 \mathrm{mg} / \mathrm{kg}$ with Nauclea diderrichii bark. In diabetic rats, Nauclea diderrichii leaf extract $(100 \mathrm{mg} / \mathrm{kg})$ brought the blood glucose levels towards normal value and maintained it at the $2^{\text {nd }}$ week. At the dose of $200 \mathrm{mg} / \mathrm{kg}$, the glycaemia returned to the normal value after two weeks post-administration. The administration of streptozotocin induced abnormalities in lipid profile, transaminases, creatinemia and parameters of oxidative stress. Administration of plant extracts improved lipid profile, liver function and antioxidant status of rats. Nauclea diderrichii leaf extract was the most potent extract than Sarcocephalus pobeguinii and Nauclea diderrichii bark extracts. Thus it is concluded from this study that, Nauclea diderrichii aqueous leaves possess a marked potential-antidiabetic activity than other extracts.

Copy Right, IJAR, 2017,. All rights reserved. 


\section{Introduction:-}

Diabetes mellitus is a chronic metabolic disorder of carbohydrate, protein and fat due to absolute or relative deficiency of insulin secretion with or without varying degree of insulin resistance (Sangeetha et al., 2014) characterized by high blood glucose. Besides hyperglycemia, several other factors, associated with diabetes, including dislipidemia or hyperlipidemia are involved in the incidence and progression of microvascular (diabetic retinopathy, and nephropathy) and macrovascular diseases (amputation, cardiovascular disease and mortality) that are difficult to manage (Menakshi et al., 2011; Prinya et al., 2012). These metabolic disorders constitute the main causes of morbidity and death in diabetic patients (Vishnu et al., 2010). Diabetes mellitus is recognized as a global major health problem (IDF, 2013). Due to a higher incidence of the risk factors, the prevalence of diabetes is increasing worldwide, but more evidently in developing countries. The number of diabetic patients worldwide is projected to rise above 300 million before 2025 (Ganiyu et al., 2012). Current estimates indicate at 69\% increase in the number of adults that would be affected by the disease between 2010 and 2030, compared to $20 \%$ for developed countries (Shaw et al., 2010). Despite considerable progress in the management of diabetes mellitus by synthetic drugs (insulin injection, oral antidiabetic drugs) and the modification of life style, the number of diabetic patients using medicinal plants for treatment continues to increase. This is due to the prominent side effects of drugs which fail to significantly alter the course of complications related to diabetes (Grover et al ., 2002).

Literature surveys summarize the benefit of several medicinal plants as anti-diabetic agents in the form of crude extracts and/or isolated pure compounds, which exhibit varying degrees of hypoglycemic or antihyperglycemic bioactivities. New drugs are continually being tested to prevent and treat diabetes. In our previously study, our team showed by in vitro study that, Nauclea diderrichii (barks and leaves) and Sarcocephalus pobeguinii (barks) are potent inhibitors of $\alpha$-glucosidase. This result justifies their popular use for the treatment of diabetes (Agnaniet et al., 2016). There is a need to confirm the activity of these extract using in vivo study. Streptozotocin induced diabetes in rats is currently used (Hayashi et al, 2006; Takeshika et al 2006; Szkudelski et al, 2011) to demonstrate antidiabetic activity of plant extracts. Therefore the present study was undertaken to evaluate the effects of Sarcocephalus pobeguinii (barks), Nauclea diderrichii (barks and leaves) on some metabolic parameters in normal and STZinduced diabetic rats.

\section{Materials and Methods:- \\ Materials:- \\ Plant material:-}

The samples of plants and extracts from Nauclea diderrichii and Sarcocephalus pobeguinii were collected and carried out as the procedures previously described by Agnaniet et al, 2016.

\section{Chemicals:-}

Streptozotocin was purchased from Sigma-Aldrich Co, USA. Glucose, Cholesterol, triglycerides, total proteins, creatinin, alanine amino-transferase (ALT), aspartate amino-transferase (AST), uric acid, total and direct bilirubin were assayed using commercial Kits from Fortress diagnostics and SGMitalia.

\section{Animals:-}

Adult male Wistar rats weighing $150-200 \mathrm{~g}$, at the beginning of experiment were obtained from animal house of Faculty of Science, University of Yaounde I, (Cameroon). They were kept in cages at standard conditions: temperature room $\left(25 \pm 2{ }^{0} \mathrm{C}\right)$ with alternating $12 \mathrm{~h}$ light/dark cycle, free access to standard food and water ad libitum. All procedures in this study followed the principles of laboratory animal use and care of the "European community" guidelines (EEC Directive 2010/63/EEC) and were approved by the "Animal Ethical Committee" of the Faculty of Science, University of Yaounde I.

\section{Experiments:-}

Effect of extracts on blood glucose levels on normal glycaemic rats:-

The hypoglycemic test was performed for $5 \mathrm{~h}$ in overnight-fasted normoglycemic rats. The rats were divided into fourteen groups of five rats each. Group 1 served as normal control and received distilled water $(1 \mathrm{~mL} / 100 \mathrm{~g} \mathrm{~B}$.W). Group 2 positive control, received Glibenclamide $5 \mathrm{mg} / \mathrm{kg}$. Group 3 to 14 , received increasing doses of extracts (50, $100,200$ or $400 \mathrm{mg} / \mathrm{kg} \mathrm{B.W})$ of extracts from S. p. ( $E_{10}$, groups $\left.3-6\right)$, N. d. ( $E_{14}$, group $7-10$; $E_{15}$, group $11-14$ ) suspended in distilled water. 
Distilled water $(1 \mathrm{~mL} / 100 \mathrm{~g} \mathrm{B.W})$, Glibenclamide $(5 \mathrm{mg} / \mathrm{kg})$ were respectively administered to the normal control (Group 1: NC) and positive control (Group 2: DC). The remaining groups (3-14) received increasing doses (50, 100, 200 or $400 \mathrm{mg} / \mathrm{kg}$ ) of leaves ( $\mathrm{E}_{14}$, group 3-6) and barks $\left(\mathrm{E}_{15}\right.$, groups 7-10) aqueous extract of $N$. diderrichii and $S$. pobeguinii aqueous extract barks $\left(\mathrm{E}_{10}\right.$, groups 11-14) respectively. Blood samples were taken from the tail vein respectively before $(0 \mathrm{~h})$ and at 1, 2, 3, 4 and $5 \mathrm{~h}$ after extracts. The blood glucose levels were mesured using accu check glucometer. Only doses exhibiting hypoglycemic activity were used to screen the antihyperglycemic activity of these plant extracts.

\section{Induction of diabetes Mellitus:-}

The animals were acclimated during two weeks in laboratory conditions before experimental work. The healthy animals: albino Wistar rats were acclimated during two weeks in laboratory conditions before experimental work. Then they were fasted overnight for 12 hours. Diabetes mellitus was induced by subcutaneous injection of a single dose of Steptozotocin $(55 \mathrm{mg} / \mathrm{kg})$ freshly dissolved in ice citrate buffer $(\mathrm{pH} \mathrm{4.5)}$ glucometer and administered subcutaneously to fourty experimental rats. Non diabetic control rats received citrate buffer only, by the same route. Hyperglycemia was confirmed in the streptozotocin-treated rats by measuring ( $72 \mathrm{~h}$ post injection) blood glucose level withdrawn from the vein tail using a glucometer. Only rats in which hyperglycemia had been successfully induced (glucose levels above $250 \mathrm{mg} / \mathrm{dL}$ ) were kept for 15 days post-injection before the beginning of the experiment to stabilize the hyperglycemic conditions. The rats with fasted blood glucose levels above $250 \mathrm{mg} / \mathrm{dL}$, after this time of stabilisation, were considered to be diabetic and were used in the experiment (Dzeufiet et al., 2006, Kesari et al 2006; Ngueguim et al, 2007).

Effects of extract on blood glucose of diabetic rats: The normal and the diabetic rats were each randomly separated into nine groups and each group consisted to five animals: Group 1 and 2 containing normal and diabetic rats respectively received distilled water $(10 \mathrm{ml} / \mathrm{kg})$. Group 3 containing diabetic rats, received Glibenclamide (5 $\mathrm{mg} / \mathrm{kg}$ ), representing the positive control. The diabetic others groups 4 to 9 were given 100 and $200 \mathrm{mg} / \mathrm{kg}$ of the extracts $\mathrm{E}_{10}, \mathrm{E}_{14}$ and $\mathrm{E}_{15}$ respectively.

Baseline fasting blood glucose levels were initially determined in all the groups. The substances were given for 14 consecutive days. Glucose levels were determined at days 7 and 14. At the end of drugs and plant extracts administration. The rats were fasted for $12 \mathrm{~h}$, sacrificed by decapitation after anesthesia with diethyl ether and blood sample collected in normal tubes. From the clotted blood at room temperature, serum was collected by centrifuging at $3000 \mathrm{~g}$ for $10 \mathrm{~min}$ to determine the glucose, cholesterol, triglyceride, total protein, creatinin, transaminases, total and direct bilirubin and uric acid levels. Organs such as aorta, heart, liver and kidney were dissected out and washed in ice saline solution to remove the blood., Homogenate $(20 \%)$ of each organ was prepared using Tris-HCl buffer $50 \mathrm{mM}$ (pH 7.4). Mc Even solution was used for the aorta and heart homogenates. The mixture obtained was centrifuged at $3500 \mathrm{~g}$ for $25 \mathrm{~min}$ at $4^{0} \mathrm{C}$. The resulting supernatant were separated for the evaluation of some parameters of oxidative stress (superoxide dismutase, catalase activities; reduced glutathione and nitrite concentrations).

Statistical analysis: Results are expressed as the mean \pm SEM. Statistical differences between control and treated group were tested by one way analysis of variance (ANOVA) followed by Tukey's test using GraphPad Prism, version 5.00 (Trial). $P$ values less than 0.05 were considered to be significant.

\section{Results:-}

Effects of extract blood glucose levels of normal rats:-

Table 1 shows the results of blood glucose monitoring performed for five hours ( 5 hours). At the doses of 50 and $100 \mathrm{mg} / \mathrm{kg}$, no diminution of blood glucose levels was observed. At dose 200 and $400 \mathrm{mg} / \mathrm{kg}$, a significant decrease of blood sugar is observed respectively from 3and 4hours after administration of extracts until the end of experiment. Thus, 200 and $400 \mathrm{mg} / \mathrm{kg}$ are more active than others.

Effects of repeated administration of extracts on blood glucose levels on normal and STZ-induced diabetic rats:-

The variation of blood glucose levels in the experimental rats are given in table 2. After seven days of treatment, there is a significant reduction of blood glucose in some groups of diabetic rats receiving treatment. Among these groups, the extracts $\mathrm{E}_{14}$ at the doses 100 and $200 \mathrm{mg} / \mathrm{kg}$ and $\mathrm{E}_{15}$ at the dose $200 \mathrm{mg} / \mathrm{kg}$ have shown a fall of $78.71 \%, 73.22 \%$ and $65.34 \%$ of blood glucose respectively as compared to the initial value (early treatment). Whereas the Glibenclamide induced a non-significant decrease in blood glucose levels (7.67\%). However after 
fourteen days of administration extracts and Glibenclamide, the different groups of rats have shown a significant decrease of glycaemia by $53.95 \%$, for $\mathrm{E}_{10}(100 \mathrm{mg} / \mathrm{kg}), 81.85 \%, 78.19 \%$ for $\mathrm{E}_{14}(100$ and $200 \mathrm{mg} / \mathrm{kg}), 69.16 \%$ for $\mathrm{E}_{15}(200 \mathrm{mg} / \mathrm{kg})$ and $71.31 \%$ for Gliben $(5 \mathrm{mg} / \mathrm{kg})$.

During the 7 and 14 days of treatment with 3 extracts $\left(\mathrm{E}_{10}\right.$ at $100 \mathrm{mg} / \mathrm{kg}, \mathrm{E}_{14}$ at 100 and $200 \mathrm{mg} / \mathrm{kg}$ and $\mathrm{E}_{15} 200 \mathrm{mg} /$ $\mathrm{kg}$ ), the diabetic rats had improvement in the normalization of the blood glucose levels. Irrespective of de sampling days, $\mathrm{E}_{14}(100$ and $200 \mathrm{mg} / \mathrm{kg}$ ) showed a better antidiabetic action, respectively by 81.85 and $78.19 \%$ than the Glibenclamide $(71 \%) . \mathrm{E}_{15}$ at the dose of $200 \mathrm{mg} / \mathrm{kg}$ had the comparable reduction (69.16) with Glibenclamide (71.36). Whereas, $E_{10}$ at the dose of $200 \mathrm{mg} / \mathrm{kg}$ and $\mathrm{E}_{15}$ at dose $100 \mathrm{mg} / \mathrm{kg}$ appeared weaker $(22.90$ and $20.05 \%$ respectively. After one to two weeks of treatment with the $E_{10}(100 \mathrm{mg} / \mathrm{kg})$, the $E_{14}(100$ and $200 \mathrm{mg} / \mathrm{kg})$ and the $\mathrm{E}_{15}(200 \mathrm{mg} / \mathrm{kg})$, the blood glucose levels returned to normal indicating that the hypoglycemic effect of the plant extracts, in the case of $N$. diderrichii (leaves), is achieved through repeated and not single administration.

Effects of the extracts on some biochemical parameters of normal an STZ-induced diabetic rats Lipid profile:-

Studies on lipid profile (Table 3 ) at the end of $14^{\text {th }}$ days of the treatment with the aqueous extracts were compared with that of the diabetic control group. There was no significant change in total cholesterol and HDL-cholesterol in the diabetic rats. However significant increase was observed in triglycerides concentration as compared to normal control. When different extracts were administered, a significant decrease of triglycerides was observed with $\mathrm{E}_{10}$ at the doses of $100 \mathrm{mg} / \mathrm{kg}(\mathrm{p}<0.01), 200 \mathrm{mg} / \mathrm{kg}(\mathrm{p}<0.05)$ and withE ${ }_{15}$ at the dose of $100 \mathrm{mg} / \mathrm{kg}$ ( $\left.\mathrm{p}<0.05\right)$. $\mathrm{E}_{14}$ failed to reduce triglycerides concentration at all doses. The administration of streptozotocin also provoked a significant increase in the LDL-cholesterol concentration. The extract $\mathrm{E}_{15}$ at the doses of 100 and $200 \mathrm{mg} / \mathrm{kg}$ significantly decreased $(\mathrm{p}<0.001)$ LDL-cholesterol while $\mathrm{E}_{10}$ at the dose of $100 \mathrm{mg} / \mathrm{kg}$ and $\mathrm{E} 14$ at the dose of $200 \mathrm{mg} / \mathrm{kg}$ ). Thus, $\mathrm{E}_{10}$ and $\mathrm{E}_{15}$ were more active than $\mathrm{E}_{14}$. Glibenclamide used in the same conditions as plant extracts significantly reduced LDL-cholesterol but failed to change other parameters.

Change in total protein, creatinin, bilirubin, transaminases and uric acid:-

Table 4 shows the effects of different extracts on some parameters of liver and kidney functions. At the end of the experimental period, various plasmatic parameters were measured in all groups. There was a significant increase ( $\mathrm{p}<$ 0.001) in ALT, AST activities and creatinin concentration as compared to normal control. However, the serum total proteins, total bilirubin, direct bilirubin and uric acid remain $(\mathrm{p}>0.05)$ unchanged when compared to normal control rats. Streptozotocin injection induced about three times the levels of transaminases in diabetic group. After administration of different treatments, significant changes were observed: ALT activity was reduced by $\mathrm{E}_{10}(\mathrm{p}<$ $0.01)$ at both doses, E14 reduced the ALT activity at doses of $100(\mathrm{p}<0.05)$ and $200 \mathrm{mg} / \mathrm{kg}(\mathrm{p}<0.01)$ and $\mathrm{E}_{15}$ at the dose of $100(\mathrm{p}<0.001)$ and $200 \mathrm{mg} / \mathrm{kg}(\mathrm{p}<0.01)$. Parallel, AST activity was reduced by $\mathrm{E}_{10}$ at both doses $(\mathrm{p}<$ $0.05)$; by $\mathrm{E}_{14}$ at the doses of 100 (p < 0.01), $200 \mathrm{mg} / \mathrm{kg}(\mathrm{p}<0.05)$ and by $\mathrm{E}_{15}$ at both doses $(\mathrm{p}<0.01)$. $\mathrm{E}_{10}$ andE $\mathrm{E}_{14}$ extracts also provoked a significant decrease $(\mathrm{p}<0.001)$, in creatinin at both doses even $\mathrm{E}_{15}$ at the dose of $100(\mathrm{p}<$ $0.05)$ and $200 \mathrm{mg} / \mathrm{kg}(\mathrm{p}<0.01)$. Total Proteins and biluribin, direct biluribin and uric acid levels remained unchanged.

\section{Effects of different plant extracts on some parameters of oxidative stress:-}

Streptozotocin administration to animals induced variations in some parameters of oxidative stress (Fig1.) depending to the organ. In SOD activity (Fig. 1A) there was a significant increasein aorta $(\mathrm{p}<0.05)$ contrary to the heart, liver and kidney where SOD activity was no significant. The plant extract $\mathrm{E}_{14}$ at the dose of $200 \mathrm{mg} / \mathrm{kg}$ administered for two weeks, provoked a significant increase in the SOD activityin the aorta while the smallest dose significantly reduced this parameter in the heart. The extract $\mathrm{E}_{15}$ at all doses failed to reduce SOD activity in organs investigated. On other hand, diabetic rats showed a significant increase in the catalase concentration (Fig. 1B) only in the aorta. The extract $\mathrm{E}_{14}$ and $\mathrm{E}_{15}$ at all doses significantly reduced $(\mathrm{p}<0.001)$ catalase concentration in the aorta as compared to the diabetic control. These extract also reduced catalase concentration in other organs whenever nonsignificant. There was no variation in GSH concentration in diabetic rat's organs (Fig. 1C). At the dose of 200 $\mathrm{mg} / \mathrm{kg}$, only the extract $\mathrm{E}_{15}$, induced a significant reduction in GSH concentration in the kidney as compared to the diabetic control. A unique dose of streptozotocin $(55 \mathrm{mg} / \mathrm{kg})$ was associated with an increase in nitrites $(\mathrm{p}>0.05)$ in aorta, heart and liver (Fig. 1D). The increase levels of nitrites were attenuated by two weeks administration of the extract $E_{14}$ at the dose of $200 \mathrm{mg} / \mathrm{kg}$ and $E_{15}$ by both doses. Glibenclamide $(5 \mathrm{mg} / \mathrm{kg})$ used as reference drug in the same conditions as the extracts, failed to reduced GSH and nitrites concentration in all organs but significantly reduced SOD activity and catalase concentration in the aorta. 


\section{Discussion:-}

The activity of three plant extracts used in Gabonese traditional medicine to manage diabetes was investigated in the present study. The results indicated that Sarcocephalus pobeguinii aqueous bark $\left(\mathrm{E}_{10}\right)$ extract, Nauclea diderrichii aqueous leaf $\left(E_{14}\right)$ and bark $\left(E_{15}\right)$ extracts reduced the glucose levels in normal rats . $E_{14}$ showed the lowest activity on blood sugar in normoglycemic rats. At equal dose $(200 \mathrm{mg} / \mathrm{kg}), \mathrm{E}_{15}$ extract was more potent than $\mathrm{E}_{10}$ extract because of the ability of the former to significantly reduce blood glucose levels 3hours post-dosing. However the effect of Glibenclamide used as reference drug was better than that of the extracts. The results also revealed that $\mathrm{E}_{15}$ (200 mg / kg) was more active than $\mathrm{E}_{15}(400 \mathrm{mg} / \mathrm{kg}$ ), we can therefore say that the hypoglycemic effect of this extract is optimal at moderate doses. Moreover, these results allowed not only to know the more potent extract with hypoglycemic effect but, also to select the doses to use in the evaluation of anti-diabetic activity on streptozotocininduced diabetic rats. Agnaniet et al., 2016 have shown that Sarcocephalus pobeguinii (barks) Nauclea. Diderrichii (leaves and barks) could be used to manage diabetes state due to their capacity to inhibit $\alpha$-glucosidase activity. In this study the administration of this different extracts for two weeks to streptozotocin induced-diabetic rats have shown a decrease in blood glucose levels towards normal value at the dose of $100 \mathrm{mg} / \mathrm{kg}$ with $\mathrm{E}_{14}$ extract one week post-administration. Parallel, $\mathrm{E}_{15}$ and $\mathrm{E}_{10}$ did not bring the glycaemia towards normal value even the treatment was continuing up to two weeks. These results suggest that, $\mathrm{E}_{14}$ extract is more potent that $\mathrm{E}_{10}$ and $\mathrm{E}_{15}$ in diabetic state. Since in acute treatment $\mathrm{E}_{15}$ was the most potent extract and $\mathrm{E}_{14}$ was the most potent extract in antidiabetic activity we can therefore say that, there is no correlation between hypoglycemic effect and antidiabetic activity. This allows us to suppose that the mode of action of the extracts is not the same.

Phenolic compounds have shown to possess a strong capacity to improve diabetic state. (Gandhi et., 2011; Yao et al., 2012). We can therefore attest that the hypoglycemic effect induced by $\mathrm{E}_{14}$ extract could be result to the presence of these secondary metabolites in the extract (Agnaniet et al., 2016). Alkaloids (Adeneye et al., 2012; Kwon et al, 2017) and saponins (Gao et al., 2016) also present in this extract are known for their hypoglycaemic activity. Taking together these observations, different secondary metabolites present in $\mathrm{E}_{14}$ extract act synergycally to induce the observed hypoglycemia activity. The hyperglycemia observed in diabetes conditions is accompanied by the lipid metabolism disorders characterized by an elevation in triglycerides, total cholesterol, LDL-cholesterol and a decrease in HDL-cholesterol. (Cam et al., 1993; Pari and Saravanan, 2002).The administration of plant extracts improved the lipid profile of diabetic rats probably due to their hypoglycemic effect. ALT and AST are key metabolic enzyme makers for liver function. The increase in these two parameters indicates hepatotoxicity which is related to glucose induce-oxidative stress (Poitout and Robertson, 2002). Infact, hyperglycemia induced autoxidation of glucose which in turn generates reative oxygen species, attacks cells and compromised membrane function thus caused leakage of these enzymes into the blood stream (Lery et al., 1999). The improvement of these enzymes by the extracts could be attributed to the presence in these extracts of triterpenes, flavonoids and phenols which are known to have an antioxidant activities (Montilla et al., 2003; Hennebele et al., 2004; Rodrigues et al, 2005). STZ induceddiabetic rats provoked a creatinemia suggesting the increase in muscular activity which was reversed by the plant extracts at all doses. In this study, permanent hyperglycemia provokes inbalance of antioxidant defence system characterized by an increase in SOD, catalase, GSH and NO mainly in the aorta. This increase attests the present of free radicals. However, the administration of the plant extract reduced these different parameters showing that $\mathrm{E}_{14}$ extract was the best extract to reduce oxidative stress.

In conclusion, Sarcocephalus pobeguinii (barks) and Nauclea diderrichii (barks and leaves) extracts could lower blood glucose levels in normal and diabetic rats. Nauclea diderrichii leaves $\left(\mathrm{E}_{14}\right)$ was the most potent extract than $\mathrm{E}_{10}$ and $\mathrm{E}_{15}$. These extracts prevented the increase in serum ALT, AST, creatinin of diabetic rats; improved lipid profile, liver functions by decreasing ALT and AST levels. More studies still to be done to isolate the active principles and to determine clearly the action mechanisms of these extracts.

Table 1:-Effects of single administration of Nauclea diderrichii $\left(\mathrm{E}_{14}\right.$ and $\left.\mathrm{E}_{15}\right)$ and Sarcocephalus pobeguinii $\left(\mathrm{E}_{10}\right)$ on blood glucose levels in normal rats

\begin{tabular}{|c|c|c|c|c|c|c|c|}
\hline \multirow[b]{2}{*}{ Treatment } & \multirow[b]{2}{*}{$\begin{array}{c}\text { Doses } \\
(\mathrm{mg} / \mathrm{kg})\end{array}$} & \multicolumn{6}{|c|}{ Blood glucose levels (mg/dL) } \\
\hline & & $\mathbf{0 h}$ & 1h & $2 \mathrm{~h}$ & $3 \mathbf{h}$ & $4 h$ & $5 \mathrm{~h}$ \\
\hline DW & 10 & $\begin{array}{c}73.25 \pm \\
1.29\end{array}$ & $\begin{array}{c}84.25 \pm \\
1.63\end{array}$ & $\begin{array}{c}72.25 \pm \\
2.27\end{array}$ & $72.5 \pm 3.28$ & $\begin{array}{c}84.75 \pm \\
3.83\end{array}$ & $79.5 \pm 2.46$ \\
\hline & & $73.50 \pm$ & $51.50 \pm$ & $37,5 \pm$ & $34.25 \pm$ & $34 \pm$ & $34 \pm 1.27 * * *$ \\
\hline
\end{tabular}




\begin{tabular}{|c|c|c|c|c|c|c|c|}
\hline Gliben & 5 & 1.67 & $6.86 * *$ & $0.82 * * *$ & $1.13 * * *$ & $0.61 * * *$ & \\
\hline \multirow{5}{*}{$\mathrm{E}_{10}$} & 50 & $74.5 \pm 2.30$ & $\begin{array}{c}81.25 \pm \\
3.37\end{array}$ & $\begin{array}{c}72.5 \pm \\
1.43\end{array}$ & $\begin{array}{c}78.25 \pm \\
0.96\end{array}$ & $\begin{array}{c}84.75 \pm \\
3.32\end{array}$ & $82.75 \pm 3.47$ \\
\hline & 100 & $\begin{array}{c}72.25 \pm \\
3.83\end{array}$ & $85 \pm 5.35$ & $\begin{array}{c}84.75 \pm \\
3.87^{*}\end{array}$ & $\begin{array}{l}88.25 \pm \\
2.72 * *\end{array}$ & $\begin{array}{c}90.25 \pm \\
4.96\end{array}$ & $86.5 \pm 3.32$ \\
\hline & 200 & $\begin{array}{c}74.25 \pm \\
7.84\end{array}$ & $\begin{array}{c}80.5 \pm \\
3.09\end{array}$ & $\begin{array}{c}75.25 \pm \\
1.55\end{array}$ & $65.5 \pm 1.25$ & $\begin{array}{c}59.5 \pm \\
0.90 * * *\end{array}$ & $\begin{array}{c}54.5 \pm \\
0.81^{* * *}\end{array}$ \\
\hline & 400 & $\begin{array}{c}70.25 \pm \\
0.96\end{array}$ & $\begin{array}{c}73.75 \pm \\
2.96\end{array}$ & $\begin{array}{c}61.5 \pm \\
2.38\end{array}$ & $\begin{array}{l}58.5 \pm \\
0.43^{* *}\end{array}$ & $\begin{array}{l}49.25 \pm \\
1.9^{* * *}\end{array}$ & $\begin{array}{l}47.75 \pm \\
2.10^{* * * *}\end{array}$ \\
\hline & 50 & $\begin{array}{c}74.25 \pm \\
1.88\end{array}$ & $\begin{array}{c}76.75 \pm \\
3.10\end{array}$ & $\begin{array}{c}69.5 \pm \\
2.83\end{array}$ & $72.5 \pm 4.72$ & $\begin{array}{c}83 \pm \\
2.26^{* * *}\end{array}$ & $80.5 \pm 0.55$ \\
\hline \multirow{3}{*}{$\mathrm{E}_{14}$} & 100 & $\begin{array}{c}73.25 \pm \\
3.20\end{array}$ & $76 \pm 4.06$ & $\begin{array}{c}80.25 \pm \\
1.63^{*}\end{array}$ & $74 \pm 1.45$ & $\begin{array}{c}82.75 \pm \\
2.53\end{array}$ & $75.5 \pm 2.61$ \\
\hline & 200 & $65.5 \pm 2.51$ & $\begin{array}{c}70.5 \pm \\
2.51\end{array}$ & $\begin{array}{c}66.25 \pm \\
1.70\end{array}$ & $74 \pm 1.27$ & $\begin{array}{c}73.75 \pm \\
0.81\end{array}$ & $73.25 \pm 0.89$ \\
\hline & 400 & $67 \pm 0.96$ & $\begin{array}{l}68.25 \pm \\
1.98\end{array}$ & $\begin{array}{c}68.5 \pm \\
1.47\end{array}$ & $68 \pm 0.61$ & $\begin{array}{l}62.5 \pm \\
1.43 * * *\end{array}$ & $\begin{array}{l}47.75 \pm \\
2.10^{* * *}\end{array}$ \\
\hline \multirow{4}{*}{$E_{15}$} & 50 & $73 \pm 2,03$ & $91 \pm 3,90$ & $\begin{array}{c}85.75 \pm \\
2.10^{*}\end{array}$ & $\begin{array}{c}83.25 \pm \\
4.27\end{array}$ & $\begin{array}{c}100.2 \pm \\
4.57\end{array}$ & $82.75 \pm 3,9$ \\
\hline & 100 & $72 \pm 3,35$ & $\begin{array}{c}80.5 \pm \\
2.41\end{array}$ & $72 \pm 3.75$ & $77 \pm 7.35$ & $\begin{array}{c}85.75 \pm \\
3.74\end{array}$ & $72.75 \pm 6.57$ \\
\hline & 200 & $\begin{array}{c}69.25 \pm \\
5.45\end{array}$ & $\begin{array}{c}64.5 \pm \\
3.28\end{array}$ & $\begin{array}{c}62.25 \pm \\
3.64\end{array}$ & $\begin{array}{l}50.5 \pm \\
0.55^{*}\end{array}$ & $\begin{array}{r}47.5 \pm \\
1.34 * * *\end{array}$ & $\begin{array}{l}45.25 \pm \\
1.13 * * *\end{array}$ \\
\hline & 400 & $67.75 \pm 2.19$ & $\begin{array}{c}69.25 \pm \\
3.20\end{array}$ & $\begin{array}{c}66.5 \pm \\
1.29\end{array}$ & $\begin{array}{c}52.50 \pm \\
1.34 *\end{array}$ & $\begin{array}{l}54.75 \pm \\
3.54 * * *\end{array}$ & $53.00 \pm 3.7^{* *}$ \\
\hline
\end{tabular}

Each value represents means $\pm \mathrm{SEM}, \mathrm{n}=5,{ }^{*} p<0.05,{ }^{* *} p<0.01,{ }^{* * * *} p<0.001$ as compared with control at the same time;Gliben:glibenclamide; $\mathrm{E}_{10}$ : aqueous extract of $S$. pobeguinii (barks); $\mathrm{E}_{14}$ :aqueous extract of $N$. diderrichii (leaves); $\mathrm{E}_{15}$ : aqueous extract of $N$. diderrichii (barks); DW: distilled water

Table 2:- Effects of repeated administration of extracts on blood glucose levels in STZ-induced diabetic rats.

\begin{tabular}{|c|c|c|c|c|c|c|}
\hline \multirow[b]{2}{*}{ Treatment } & \multirow[b]{2}{*}{ Doses } & \multicolumn{5}{|c|}{ Blood glucose levels $(\mathrm{mg} / \mathrm{dL})$} \\
\hline & & Day 0 (D0) & Day 7 (D7) & $\begin{array}{l}\% \\
\text { variation } \\
\text { D7 }\end{array}$ & Day 14 (D14) & $\begin{array}{l}\% \\
\text { variation } \\
\text { D14 }\end{array}$ \\
\hline N.C & $10 \mathrm{ml} / \mathrm{kg}$ & $59.50 \pm 0.28$ & $59.75 \pm 0,47$ & -0.42 & $58.25 \pm 2.810$ & 2.10 \\
\hline D.C & $10 \mathrm{ml} / \mathrm{kg}$ & $\begin{array}{l}399.5 \pm \\
37.05\end{array}$ & $442.3 \pm 48,65$ & -10.71 & $348.3 \pm 12,34$ & 12.81 \\
\hline Gliben & $5 \mathrm{mg} / \mathrm{kg}$ & $\begin{array}{c}354.5 \pm \\
28.42 \\
\end{array}$ & $327.3 \pm 52,28$ & 7.67 & $\begin{array}{c}101.5 \pm \\
15.93 * * *\end{array}$ & 71.36 \\
\hline \multirow[t]{2}{*}{$\mathrm{E}_{10}$} & $100 \mathrm{mg} / \mathrm{kg}$ & $337 \pm 17.34$ & $441 \pm 28.00$ & -30.86 & $\begin{array}{c}155.5 \pm \\
38.54 * * *\end{array}$ & 53.95 \\
\hline & $200 \mathrm{mg} / \mathrm{kg}$ & $\begin{array}{c}466.66 \pm \\
44.77\end{array}$ & $436 \pm 3.00$ & 6.57 & $359.75 \pm 14.63$ & 22.90 \\
\hline \multirow{2}{*}{$\mathrm{E}_{14}$} & $100 \mathrm{mg} / \mathrm{kg}$ & $478 \pm 16.00$ & $\begin{array}{l}101.75 \pm \\
1.65^{* * *}\end{array}$ & 78.71 & $86.75 \pm 5.64 * * *$ & 81.85 \\
\hline & $200 \mathrm{mg} / \mathrm{kg}$ & $\begin{array}{c}412.75 \pm \\
20.81\end{array}$ & $\begin{array}{l}110.5 \pm \\
7.32 * * *\end{array}$ & 73.22 & $90 \pm 8.45^{* * *}$ & 78.19 \\
\hline \multirow[b]{2}{*}{$E_{15}$} & $100 \mathrm{mg} / \mathrm{kg}$ & $400 \pm 37.84$ & $349.8 \pm 18,38$ & 12.55 & $299.8 \pm 77.68$ & 25.05 \\
\hline & $200 \mathrm{mg} / \mathrm{kg}$ & $\begin{array}{c}393.3 \pm \\
28.62\end{array}$ & $\begin{array}{c}136.3 \pm \\
24.63 * * *\end{array}$ & 65.34 & $121.3 \pm 7.718^{* *}$ & 69.16 \\
\hline
\end{tabular}

Each value represents means \pm SEM, $\mathrm{n}=5,{ }^{* * *} p<0.01,{ }^{* * * *} p<0.001$ as compared with diabetic control. Distilled water: NC; Distilled water: D.C ; Glibenclamide :Gliben ;S. pobeguinii barks : $\mathrm{E}_{10} ; N$ diderrichii Leaves: $\mathrm{E}_{14} ; N$. diderrichii barks : $E_{15}$ 
Table 3:- Effect of the tree extracts on lipid profile of normal and STZ-induced diabetic rats.

\begin{tabular}{|c|c|c|c|c|c|}
\hline \multirow{2}{*}{ Treatment } & \multirow{2}{*}{ Doses } & \multicolumn{4}{|c|}{ Parameters } \\
\cline { 2 - 6 } & & $\begin{array}{c}\text { T. Chol } \\
(\mathbf{m g} / \mathbf{d L})\end{array}$ & $\begin{array}{c}\text { Triglycerides } \\
(\mathbf{m g} / \mathbf{d L})\end{array}$ & $\begin{array}{c}\text { HDL-Chol } \\
(\mathbf{m g} / \mathbf{d L})\end{array}$ & $\begin{array}{c}\text { LDL-Chol } \\
(\mathbf{m g} / \mathbf{d L})\end{array}$ \\
\hline N.C & $10 \mathrm{ml} / 1 \mathrm{~kg}$ & $35.13 \pm 6.28$ & $24.22 \pm 1.49$ & $19.44 \pm 3.18$ & $9.52 \pm 6.22$ \\
\hline D.C & $10 \mathrm{ml} / 100 \mathrm{~g}$ & $37.58 \pm 7.42$ & $61.43 \pm 1.28^{*}$ & $22.24 \pm 2.57$ & $31.48 \pm 3.21 * * *$ \\
\hline Gliben & $5 \mathrm{mg} / \mathrm{kg}$ & $31.55 \pm 4.87$ & $52.02 \pm 22.74$ & $17.35 \pm 0.86$ & $7.7815 \pm 3.07 * * *$ \\
\hline $\mathrm{E}_{10}$ & $100 \mathrm{mg} / \mathrm{kg}$ & $30.69 \pm 2.70$ & $16.95 \pm 0.73 * *$ & $21.09 \pm 0.56$ & $6.20 \pm 2.11^{*} * *$ \\
\hline \multirow{2}{*}{$\mathrm{E}_{14}$} & $200 \mathrm{mg} / \mathrm{kg}$ & $42.08 \pm 0.95$ & $22.71 \pm 9.18^{*}$ & $16.41 \pm 2.19$ & $21.12 \pm 1.39$ \\
\hline $\mathrm{E}_{15}$ & $100 \mathrm{mg} / \mathrm{kg}$ & $64.18 \pm 4.69 * *$ & $61.06 \pm 15.55$ & $26.13 \pm 2.21$ & $25.84 \pm 3.49 \#$ \\
\cline { 2 - 6 } & $200 \mathrm{mg} / \mathrm{kg}$ & $46.25 \pm 2.41$ & $47.65 \pm 10.65$ & $22.35 \pm 0.80$ & $14.36 \pm 2.34 *$ \\
\hline & $100 \mathrm{mg} / \mathrm{kg}$ & $26.01 \pm 1.74$ & $24.51 \pm 4.41 *$ & $19.76 \pm 2.48$ & $7.13 \pm 0.46^{* * *}$ \\
\cline { 2 - 6 } & $200 \mathrm{mg} / \mathrm{kg}$ & $31.39 \pm 1.35$ & $30.78 \pm 7.58$ & $17.81 \pm 0.58$ & $7.30 \pm 0.85 * * *$ \\
\hline
\end{tabular}

Each value represents means $\pm \mathrm{SEM}, \mathrm{n}=5, p<0.05,{ }^{* *} p<0.01$ compared with diabetic control. ${ }^{\#} p<0.05$ as compared with normal control.Distilled water:N.C;Distilled water:D.C ; Glibenclamide :Gliben ;S. pobeguiniibarks $: \mathrm{E}_{10} ; N$ diderrichii Leaves: $\mathrm{E}_{14} ; N$. diderrichii barks $: E_{15}$

Table 4:- Effect of the tree extracts on some parameters of kidney and liver functions of STZ-induced diabetic rats.

\begin{tabular}{|c|c|c|c|c|c|c|c|c|}
\hline \multirow[t]{2}{*}{ Treatment } & \multirow[b]{2}{*}{ Doses } & \multicolumn{7}{|c|}{ Parameters } \\
\hline & & $\begin{array}{l}\text { Proteins } \\
\text { (mg/dL) }\end{array}$ & $\begin{array}{c}\text { Crea } \\
(\mathrm{mg} / \mathrm{dL})\end{array}$ & $\begin{array}{c}\text { T. Bil } \\
\text { (mg/dL) }\end{array}$ & $\begin{array}{c}\text { D. Bil } \\
(\mathrm{mg} / \mathrm{dL})\end{array}$ & $\begin{array}{l}\text { ALT } \\
\text { (U/I) }\end{array}$ & $\begin{array}{l}\text { AST } \\
\text { (U/I) }\end{array}$ & $\begin{array}{l}\text { Uric acid } \\
\text { (mg/dL) }\end{array}$ \\
\hline N.C & $10 \mathrm{ml} / 1 \mathrm{~kg}$ & $\begin{array}{c}12.74 \pm \\
0.11\end{array}$ & $\begin{array}{c}1.55 \pm \\
0.71\end{array}$ & $\begin{array}{c}0.90 \pm \\
0.01\end{array}$ & $\begin{array}{c}0.40 \pm \\
0.12\end{array}$ & $\begin{array}{c}46.89 \pm \\
9.47\end{array}$ & $\begin{array}{c}6328 \pm 10 \\
72\end{array}$ & $\begin{array}{c}1.02 \pm \\
0.15\end{array}$ \\
\hline D.C & $\begin{array}{c}10 \\
\mathrm{ml} / 100 \mathrm{~g}\end{array}$ & $\begin{array}{c}9.76 \pm \\
0.45\end{array}$ & $\begin{array}{l}7.14 \pm \\
\text { 09\#\#\#. }\end{array}$ & $\begin{array}{c}0.79 \pm \\
0.01\end{array}$ & $\begin{array}{c}0.40 \pm \\
0.03\end{array}$ & $\begin{array}{c}167.9 \pm \\
26.28 \# \# \#\end{array}$ & $\begin{array}{l}193.5 \pm \\
2.63 \# \# \#\end{array}$ & $\begin{array}{c}2.00 \pm \\
0.21\end{array}$ \\
\hline Gliben & $5 \mathrm{mg} / \mathrm{kg}$ & $\begin{array}{c}10.43 \pm \\
0.18\end{array}$ & $\begin{array}{c}1.47 \pm \\
0.51 * * *\end{array}$ & $\begin{array}{c}1.17 \pm \\
0.05\end{array}$ & $\begin{array}{c}0.60 \pm \\
0.11\end{array}$ & $\begin{array}{c}59.41 \\
\pm 29.76^{*}\end{array}$ & $\begin{array}{c}113.7 \pm \\
13.74 * \# \#\end{array}$ & $\begin{array}{c}1.75 \pm \\
0.15\end{array}$ \\
\hline \multirow{2}{*}{$E_{10}$} & $\begin{array}{c}100 \\
\mathrm{mg} / \mathrm{kg}\end{array}$ & $\begin{array}{c}10.80 \pm \\
0.49\end{array}$ & $\begin{array}{c}2.64 \pm \\
0.76 * * *\end{array}$ & $\begin{array}{c}0.75 \pm \\
0.01\end{array}$ & $\begin{array}{c}0.40 \pm \\
0.14\end{array}$ & $\begin{array}{l}57.81 \pm \\
3.14 * *\end{array}$ & $\begin{array}{l}120.0 \pm \\
5.22 * \# \#\end{array}$ & $\begin{array}{c}2.50 \pm \\
0.38\end{array}$ \\
\hline & $\begin{array}{c}200 \\
\mathrm{mg} / \mathrm{kg}\end{array}$ & $\begin{array}{c}10.58 \pm \\
0.10\end{array}$ & $\begin{array}{c}1.91 \pm \\
0.26 * * *\end{array}$ & $\begin{array}{c}0.99 \pm \\
0.02\end{array}$ & $\begin{array}{c}0.38 \pm \\
0.05\end{array}$ & $\begin{array}{l}81.95 \pm \\
0.89 * *\end{array}$ & $\begin{array}{c}146.5 \pm \\
22.75^{* \# \#}\end{array}$ & $\begin{array}{c}2.14 \pm \\
0.41\end{array}$ \\
\hline \multirow{2}{*}{$E_{14}$} & $\begin{array}{c}100 \\
\mathrm{mg} / \mathrm{kg}\end{array}$ & $\begin{array}{c}13.61 \pm \\
0.89\end{array}$ & $\begin{array}{c}0.77 \pm \\
0.07 * * *\end{array}$ & $\begin{array}{c}0.91 \pm \\
0.03\end{array}$ & $\begin{array}{c}0.21 \pm \\
0.02\end{array}$ & $\begin{array}{l}90.76 \pm \\
28.60 *\end{array}$ & $\begin{array}{c}74.72 \pm \\
10.20 * *\end{array}$ & $\begin{array}{c}1.30 \pm \\
0.08\end{array}$ \\
\hline & $\begin{array}{c}200 \\
\mathrm{mg} / \mathrm{kg}\end{array}$ & $\begin{array}{c}12.11 \pm \\
1.71\end{array}$ & $\begin{array}{c}1.97 \pm \\
0.59 * * *\end{array}$ & $\begin{array}{c}1.00 \pm \\
0.01\end{array}$ & $\begin{array}{c}0.25 \pm \\
0.01\end{array}$ & $\begin{array}{l}75.59 \pm \\
3.42 * *\end{array}$ & $\begin{array}{l}128.4 \pm \\
46.19 *\end{array}$ & $\begin{array}{c}1.22 \pm \\
0.12\end{array}$ \\
\hline \multirow{2}{*}{$E_{15}$} & $\begin{array}{c}100 \\
\mathrm{mg} / \mathrm{kg}\end{array}$ & $\begin{array}{c}8.90 \pm \\
0.35\end{array}$ & $\begin{array}{l}3.96 \pm \\
0.67 *\end{array}$ & $\begin{array}{c}0.85 \pm \\
0.06\end{array}$ & $\begin{array}{c}0.50 \pm \\
0.07\end{array}$ & $\begin{array}{l}32.59 \pm \\
7.68 * * *\end{array}$ & $\begin{array}{c}76.78 \pm \\
6.54 * *\end{array}$ & $\begin{array}{c}0.97 \pm \\
0.03\end{array}$ \\
\hline & $\begin{array}{c}200 \\
\mathrm{mg} / \mathrm{kg}\end{array}$ & $\begin{array}{c}10.26 \pm \\
0.63\end{array}$ & $\begin{array}{l}1.65 \pm \\
0.59 * *\end{array}$ & $\begin{array}{c}1.01 \pm \\
0.02\end{array}$ & $\begin{array}{c}0.61 \pm \\
0.07\end{array}$ & $\begin{array}{l}87.45 \pm \\
33.94 * *\end{array}$ & $\begin{array}{l}119.6 \pm \\
2.16^{* *}\end{array}$ & $\begin{array}{c}2.06 \pm \\
0.30\end{array}$ \\
\hline
\end{tabular}

Each value represents means $\pm \mathrm{SEM}, \mathrm{n}=5,{ }^{*} p<0.05, \stackrel{{ }^{* * *} p<0.01,}{p}, p<0.001$ as compared with diabetic control. ${ }^{\# \#} p$ $<0.01,{ }^{\# \# \#} p<0.001$ as compared with normal control. Distilled water:NC; Distilled water: D.C ;

Glibenclamide :Gliben $; S$. pobeguinii barks $: \mathrm{E}_{10} ; N$ diderrichii Leaves: $\mathrm{E}_{14} ; N$. diderrichii barks $: E_{15}$ 

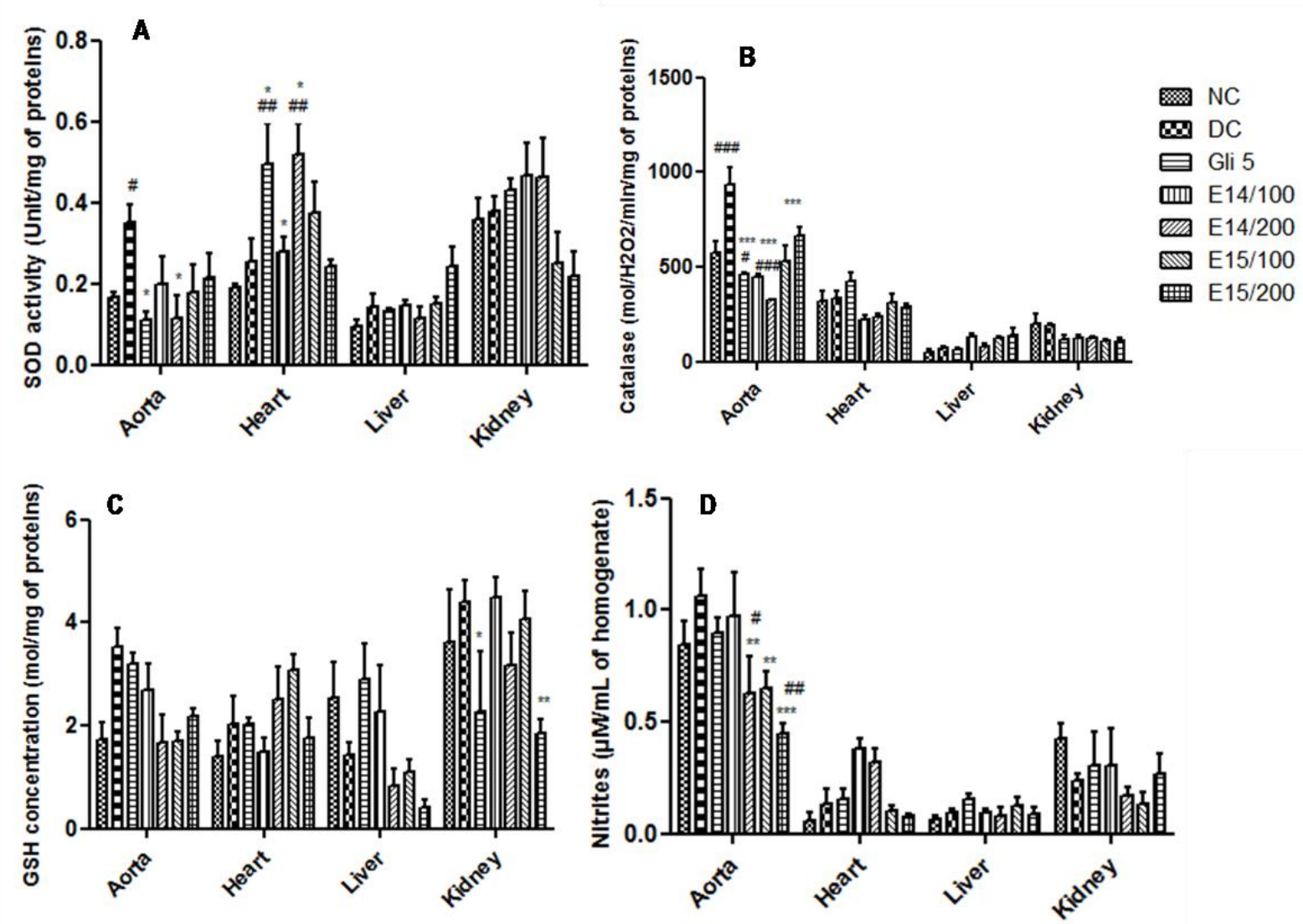

Figure 1:-Effects of the aqueous extract of Sarcocephalus pobeguinii and Nauclea diderrichii on SOD activity (A), catalase activity (B), reduced glutathione (C) and Nitrites (D) concentrations;

Each bar represents means \pm SEM, $\mathrm{n}=5,{ }^{*} p<0.05,{ }^{* *} p<0.01,{ }^{* * * *} p<0.001$ as compared with diabetic control. ${ }^{*} p<$

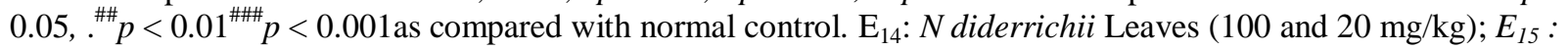
$N$ : diderrichii barks (100 and $20 \mathrm{mg} / \mathrm{kg})$ :

\section{Acknowledgements:-}

We are mostly grateful to Ulrich Carlos Mbiakop and Carole Agnès Ouafo, from the Laboratory of Animal Physiology, Faculty of Sciences, University of Yaounde I, Cameroon for their assistance and contribution in this work.

We are also mostly grateful to the Gabonese National Scholarship Agency for the airfare provided (ANBG).

\section{References:-}

1. Agnaniet, H., Mbot, E.J. Keita O., Fehrentz, J-A., Ankili, G.A.A, et al. (2016): Antidiabetic potential of two medicinal plants used in Gabonese folk medicine. BMC Complement. Altern. Med., 16: 71, DOI 10.1186/s12906-016-1052-x

2. Adeneye, A.A., Adeyemi O.O., Agbaje, E.O., Sofidiya, M.O. (2012): The novel antihyperglycemic action of Hunteria umbellata seed fractions mediated via intestinal glucose uptake inhibition. Afr J Trad Compl Alt Med., 9(1):17-24.

3. Cam, C.M., Cros, H.G., Serrano, J.J., Lazaro, R., McNeill, H.J., (1993): In vivo antidiabetic actions of naglivan, an organic vanadyl compound in streptozotocin-induced diabetes. Diabetes Res. Clin. Pract., 20: 111-121.

4. Dzeufiet, Djomeni, P.D., Tedong, L., Asongalem, E.A., Dimo, T., Sokeng, S.D., Kamtchuing, P. et al. (2006): Hypoglycemic effect of methylene chloride/methanol root extract of Ceiba pentadra in normal and diabetic rats. Indian J. Pharmacol., 38 (3): 194-197.

5. Gandhi, G.R., Ignacimuthu, S., Paulraj, M.G. (2011): Solanum torvum Swartz fruit containing phenolic compounds shows antidiabetic and antioxidant effects in streptozotocin induced diabetic rats. Food Chem Toxicol., 49: 2725 
6. Ganiyu O., Adedayo O.A., Ayodele J.A., Thomas Henleb, J.A.S., Uwe S., (2012) : Inhibitory effect of polyphenol-rich extracts of jute leaf (Corchorus olitorius) on key enzyme linked to type 2 diabetes ( $\alpha$-amylase and $\alpha$-glucosidase) and hypertension (angiotensin I converting) in vitro. J. Funct. Foods, 4 (2): 450-458.

7. Gao, D., Zhao M, Qi X, Liu Y, Li N, Liu Z, Bian, Y. (2016): Hypoglycemic effect of Gynostemma pentaphyllum saponins by enhancing the Nrf2 signaling pathway in STZ-inducing diabetic rats. Arch Pharm Res, 39(2):221-30.

8. Grover, J.K., Yadav, S., Vats, V. (2002): Medicinal plants of India with anti-diabetic potential. J.Ethnopharmacol., 81: 81-100.

9. Hayashi, K., Kojima, R., Ito, M. (2006): Strain differences in the diabetogenic activities of streptozotocin in mice. Biol. Pharm. Bull., 29: 1110-1119.

10. Hennebelle, T., Sahpaz, S., Bailleul, F. (2004): Polyphenols vegetaux sources-utilisation et potentiel dans la lutte contre le stress oxydatif. Rev. Phytother., 1: 1-5.

11. IDF International Diabetes Federation, (2013): Diabetes Atlas. 6th ed. Brussels.1-2

12. Kesari, A.N., Gupta, R.K., Singh, S.K., Diwakar, S., Watal, G., (2006): Hypoglycemic and antihyperglycemic activity of Aegle marmelos seed extract in normal and diabetic rats. J. Ethnopharmacol., 107: 374-379.

13. Kwon, S.J., Hwang, S.J., Jung, Y., Park, H.G., Kim, M.H., Park, Y., Lee, H.J. (2017): A synthetic Nitraria alkaloid, isonitramine protects pancreatic $\beta$-cell and attenuates postprandial hyperglycemia. Metabolism., 70:107-115.

14. Lery, V, Zaltzber, H., Ben-Amotz, A., Kanter, Y., Aviram, M. (1999): Carotene affects antioxidant status in non-insulin dependent diabetes mellitus.Pathophysiology, 6: 157-62.

15. Menakshi, B., Smita, S.Z., Shobha, Y.B., Ameeta, R., Bimba, N.J. (2011): Antidiabetic Indian Plants: A Good Source of Potent Amylase Inhibitors. Evidence-Based Compl. Alt. Medicine., 1-6.

16. Montilla, M.P., Agil, A., Navarro, M.C. et al, (2003): Antioxidant activity of Maslinic acid, a Triterpene derivative obtain from Olea europaea. Planta med., 69: 472-474.

17. Ngueguim, T., F., Dimo, T., Dzeufiet, D.P.D., Vouffo, B., Ndongo, E..R.B, et al. (2007): Antidiabetic activity of methanol-derived extract of dorstenia picta twigs in normal and streptozotocin-induced rats. Asian J. Tradit Med., 2(4).

18. Pari, L., Saravanan, G. (2002): Antidiabetic effect of Cogent db, a herbal drug in alloxan-induced diabetes mellitus. Comp. Biochem. Physiol. Part C, 131: 19-25.

19. Prinya, W., Jiranun, C., Anis, Z. (2012):In vitro screening of phenolic compounds, potential inhibition against $\alpha$-amylase and $\alpha$ - glucosidase of culinary herbs in Thailand. Food Chem., 131: 964-971.

20. Pushparaj, N.P., Tan, H.K.B., Tan H.C. (2001): The mechanism of hypoglycemic action of the semi purified fractions of Averrhoa bilimbi in streptozotocin-diabetic rats. Life Sci., 70: 535-547.

21. Poitout, V., Robertson, R.P. Minireview: (2002): Secondary beta-cell failure in type 2 diabetes-a convergence of glucotoxicity and lipotoxicity. Endocrinol., 143: 339-42.

22. Rodrigues, H.G., Diniz, Y. S., Faine, L.A., et al. (2005): Antioxidant effect of saponins: potential action of a soybean flavonoid on glucose tolerance and risk factors for atherosclerosis. Int J food Sci Nutr, 56(2): 79-85.

23. Sangeetha, M.S., Priyanga, S., Hemmalakshmi, S., Devaki, K. (2014):In vivo antidiabetic potential of Cyclea peltata in streptozotocin-induced diabetic rats. Asian J.Pharm Clin Res., 8(1): 103-108.

24. Shaw, J.E., Sicree, R.A., Zimmet, P.Z. (2010): Global estimetes of the prevalence of diabetes for 2010 and 2030. Diabetes Res. Clin. Pract., 87(1): 4-14.

25. Szkudelski, T., Szkudelska, K. (2011): Anti-diabetic effect of resveratrol. Ann.N. Y. Acad. Sci., 125: $34-39$.

26. Takeshika, F., Kodama, M., Yamamoto, H., Ikarashi, Y., Veda, S., Teratani, T., Yamamoto, Y., Tamatani, T., Kanegasaki, S., O’Chiya, T., Quin, G. (2006): Streptozotocin induced partial $\beta$-Cell depletion in nude mice without hyperglycemia induces pancreatic morphogenesis in transplanted embryonic stem cells. Diabetologia., 49: 2948-2958.

27. Vishnu, B., Asuti, N., Kamat, A., Sikarwar, M.S., Patil, M.B. (2010): Antidiabetic activity of insulin plant (Costus igneus) leaf extract in diabetic rats. J. Pharm. Res., 3(3): 608-611.

28. Xu, Y.J., Foubert, K., Dhooghe, L., Lemiere, F., Cimanga, K., Mesia, K., et al. (2012): Chromatographic profiling and identification of two new iridoid-indole alkaloids by UPLC-MS and HPLC-SPE-NMR analysis of an antimalarial extract from Nauclea pobeguinii. Phytochem. Lett., 5: 316.

29. Yao, Y., Cheng, X.Z., Wang, L.X., Wang, S.H., Ren, G. (2012): Major phenolic compounds, antioxidant capacity and antidiabetic potential of Rice bean (Vigna umbellata L.) in China. Int. J. Mol. Sci., 13:2707. 